\title{
Vertical distribution and transport of molybdenum in a lake with a seasonally anoxic hypolimnion
}

\section{B. Magyar and H. C. Moor}

Institute of Inorganic Chemistry, Swiss Federal Institute of Technology (ETHZ), ETH-Zentrum, CH-8092 Zurich

\section{Sigg}

Swiss Federal Institute for Water Resources and Water Pollution Control (EAWAG), Swiss Federal Institute of Technology (ETHZ), CH-8600 Dübendorf

\begin{abstract}
Distribution and trends of Mo concentrations in the seasonally anoxic Lake Greifen were investigated over 15 months. Mo in water samples and settling particles was determined by catalytic adsorption polarography and inductively coupled plasma mass spectrometry. Mo concentrations in the epilimnion were usually homogeneous at $\sim 0.48 \mu \mathrm{g} \mathrm{liter}^{-1}$. A significant decrease with depth was found during the stratification period. The lowest Mo concentrations $\left(0.31 \mu \mathrm{g}^{\text {liter }}{ }^{-1}\right)$ were found in the presence of $\mathrm{H}_{2} \mathrm{~S}$ near the sediment. A vertical flux of particle-bound Mo of $1.1-4.6 \mu \mathrm{g} \mathrm{m}^{-2} \mathrm{~d}^{-1}$ was found. The Mo concentration-depth profiles result from a combination of different transport mechanisms that are compared by computer model calculations.
\end{abstract}

Under oxic conditions, the vertical distribution of molybdenum in natural waters is highly conservative. Such a behavior was observed in the Pacific Ocean (Collier 1985; Nakayama et al. 1989) and in Lake Constance (Stabel et al. 1991). The most abundant species of Mo in aquatic environments is molybdate, $\mathrm{MoO}_{4}{ }^{2-}$. The thermodynamic stability of this species and the low $p K a$ value between 3.5 and 4 cause its generally high mobility in natural waters. In anoxic sea basins, the concentration of Mo decreases with depth (Emerson and Huested 1991). Mo is enriched in anoxic sea sediments (Manheim and Landergren 1978; Koide et al. 1986). Three processes for the transport of Mo from the water into the sediment have been proposed: coprecipitation of $\mathrm{MoS}_{3}$ or $\mathrm{MoS}_{2}$ on FeS in the presence of $\mathrm{H}_{2} \mathrm{~S}$ (Sugawara et al. 1961; Bertine 1972; Van der Weijden et al. 1990); coprecipitation of $\mathrm{MoO}_{4}{ }^{2-}$ on $\mathrm{MnOOH}$ and $\mathrm{MnO}_{2}$ under oxic conditions (Berrang and Grill 1974; Sugawara et al. 1961); and complexation by organic matter, eventually after reduction of $\mathrm{MoO}_{4}{ }^{2-}$ to Mo(V) (Brumsack and Gieskes 1983). Most

\footnotetext{
Acknowledgments

We thank Annette Kuhn and David Kistler for sampling and analytical work, Markus Ulrich for his introduction into the CHEMSEE program and lake data, and Hans Rudolf Elsener for statistical advice.

This project was supported by the credit for research and education of the ETHZ.
}

studies refer to seawater. Only the work of Sugawara et al. (1961) contains a discussion of Mo transport in lakes. Research on Mo in seawater has been possible because Mo concentrations are higher than in lake water. Indeed, no analytical method was available for the direct determination of $\mathrm{Mo}$ in freshwater until a few years ago.

Catalytic adsorption polarography (CAPOL), introduced in 1986 (Magyar and Wunderli 1986), allows direct determination of $\mathrm{Mo}(\mathrm{VI})$ in lake water in the concentration range of 0.01-10 $\mu \mathrm{g} \mathrm{liter}^{-1}$ with good precision and accuracy. This method is selective for all $\mathrm{Mo}(\mathrm{VI})$ species $\left(\mathrm{MoO}_{4}{ }^{2-}\right.$ and the protonated forms $\mathrm{HMoO}_{4}{ }^{-}$and $\mathrm{H}_{2} \mathrm{MoO}_{4}$ ). The different thiomolybdates $\left(\mathrm{MoO}_{\mathrm{n}} \mathrm{S}_{4-n}{ }^{2-}\right)$, which exist in the presence of $\mathrm{HS}^{-}$, are also measured because of the stability of the formed oxine chelate complex. $\mathrm{Mo}(\mathrm{V})$ is very easily oxidized and is measured by the method, but colloidal $\mathrm{MoS}_{2}$, which is insoluble in aqueous solutions, is not detected. Comparable sensitivity can be achieved by inductively coupled plasma mass spectrometry (ICP-MS), which has been commercially available for the last few years.

The aim of this work was to study the distribution of Mo over time and depth in a eutrophic lake with a seasonally anoxic hypolimnion. Eutrophication, due to elevated input of nutrients from agriculture and sewage, is occurring in many lakes in Switzerland. In Lake 
Greifen, the high production of algal biomass and the subsequent consumption of oxygen during mineralization cause anoxic conditions in the hypolimnion during summer stagnation. Redox conditions in the lake were discussed by Sigg et al. (1991).

Determinations of Mo were carried out by CA-POL. Some analyses were also made by ICP-MS to evaluate the reliability of CA-POL results. As the formation of sulfides may influence the concentration of Mo, hydrogen sulfide was determined by molecular absorption spectrometry (MAS) using the methylene blue procedure. Settling particles were collected, digested with aqua regia, and analyzed by ICPMS.

Model calculations of depth profiles with the computer program CHEMSEE (Ulrich 1991) were used to aid interpretation of transport mechanisms and chemical processes of a species in the lake. This approach was successfully used to model the cycling of $\mathrm{Mn}$ in the lake (Johnson et al. 1991). Different transport mechanisms for Mo are proposed and model calculations compared to field data.

\section{Experimental}

Sampling and pretreatment-Lake Greifen has a surface area of $8.5 \mathrm{~km}^{2}$ and a maximum depth of $32.2 \mathrm{~m}$. Samples were taken at the deepest site in the lake. Between August 1989 and January 1991, 13 samplings of lake water were carried out at 11 depths between 0 and $31 \mathrm{~m}$. A Niskin sampling bottle (model 1080, General Oceanics) was used. All bottles and vessels were first cleaned with $30 \% \mathrm{HNO}_{3}$ and rinsed with deionized and Milli-Q-water. Bottles for Mo analyses were also cleaned with $20 \% \mathrm{NaOH}$. These samples were kept for analyses by CA-POL without any addition of acid. Samples for the analysis by ICP-MS were acidified to $0.1 \mathrm{~mol} \mathrm{liter}^{-1} \mathrm{HNO}_{3}$ by adding the necessary quantity of acid to the flasks before adding the water sample. Some water samples were first filtered by a membrane filter (Durapore from Millipore; pore diam, $0.45 \mu \mathrm{m}$ ) and acidified after filtration. Water samples for the determination of $\mathrm{HS}^{-}$were taken into flasks that contained $\mathrm{ZnCl}_{2}$ and gelatin for the fixation of HS ${ }^{-}$(Sonnenschein and Schäfer 1953).

During 15 months, from November 1989 to January 1991, settling particles were collected with homemade sediment traps with a collec- tion surface of $157.1 \mathrm{~cm}^{2}$ (Kuhn 1992). The traps were placed in the deepest part of the lake at depths of 15 and $28 \mathrm{~m}$. The material from the traps was collected every 3 weeks and stored freeze-dried until analysis (Kuhn 1992). A subsample of $\sim 50 \mathrm{mg}$ was perfused with a small quantity of water in a low-pressure vessel. After the addition of $6 \mathrm{ml}$ of $\mathrm{HCl}(30 \%)$ and $2 \mathrm{ml}$ of $\mathrm{HNO}_{3}(65 \%)$, the sample was digested in a microwave digestion device for 15 min at an input power of $600 \mathrm{~W}$. Under these conditions, even the very stable and insoluble $\mathrm{MoS}_{2}$ is oxidized to $\mathrm{MoO}_{4}{ }^{2-}$. The recovery of the digestion procedure was determined by digesting a $\mathrm{MoS}_{2}$ sample and found to be $100.1 \%$.

Determinations by catalytic adsorption polarography (CA-POL)-Determinations by CA-POL were carried out as described by Magyar and Wunderli (1986). The only modification consisted of omitting $\mathrm{KCl}$ in the supporting electrolyte to achieve higher sensitivity. A mixture of $0.1 \mathrm{~mol} \mathrm{liter}^{-1}$ of $_{2} \mathrm{H}_{2}$ and of $0.2 \mathrm{mmol}^{\text {liter }}{ }^{-1}$ of the chelating agent $\mathrm{H}_{2} \mathrm{~L}$ (=7-nitro-8-hydroxyquinoline-5-sulfonic acid) was used. All measurements were carried out by a polarograph of type Polarecord E506 (Metrohm AG, Herisau). It was cquipped with a model 648 electrode stand, a dropping mercury electrode (DME), a Pt-rod auxiliary electrode, and a double-junction reference electrode: $\mathrm{Ag} / \mathrm{AgCl} / \mathrm{KCl}(3 \mathrm{M}) / \mathrm{KCl}(0.35 \mathrm{M})$, $\mathrm{H}_{2} \mathrm{SO}_{4}(0.05 \mathrm{M})$. A drop time of $1 \mathrm{~s}$ was selected, corresponding to a drop surface area of $0.97 \mathrm{~mm}^{2}$. The technique of differential pulse polarography was used with $-0.8 \mathrm{~V}$ starting potential, a scan rate of $-6 \mathrm{mVs}{ }^{1}$, and a pulse amplitude of $50 \mathrm{mV}$.

Determinations by ICP-MS-An ICP-MS system PlasmaQuad PQ 2 Plus from VG Elemental was used. The instrument is equipped with a $27.12 \mathrm{MHz}$ generator which was operated at a power of $1.35 \mathrm{~kW}$. A Meinhardtype concentric glass capillary nebulizer was used. The volume flow rates of Ar were usually 0.790 liter $\mathrm{min}^{-1}$ for the nebulization, 0.8 liter min $^{-1}$ intermediate gas, and 13 liter $\min ^{-1}$ cooling gas. A sampling cone and skimmer cone made of $\mathrm{Ni}$ with drillings of 1.0 and $0.7 \mathrm{~mm}$, respectively, were used.

Data collection for the determinations of water samples was carried out in the peak jumping mode with a dwell time of $20.48 \mathrm{~ms}$ at seven points per peak. Three runs for each 
solution were taken with 20 peak jump swecps. The isotopes ${ }^{55} \mathrm{Mn},{ }^{98} \mathrm{Mo},{ }^{115} \mathrm{In}$, and ${ }^{184} \mathrm{~W}$ were measured. All water samples were spiked with $50 \mu \mathrm{g} \mathrm{liter}{ }^{-1}$ of In as the internal standard element.

Data collcction for the determinations of the digested solutions of the settling particles was carried out measuring seven points per peak, 25 peak jump sweeps, and three runs for each solution, with individual dwell times for each isotope between 0.640 and $40.96 \mathrm{~ms}$ to achieve the same precision for all isotopes. The measured isotopes were ${ }^{95} \mathrm{Mo},{ }^{97} \mathrm{Mo},{ }^{98} \mathrm{Mo},{ }^{111} \mathrm{Cd}$, ${ }^{112} \mathrm{Cd},{ }^{115} \mathrm{In},{ }^{205} \mathrm{Tl},{ }^{206} \mathrm{~Pb},{ }^{207} \mathrm{~Pb}$, and ${ }^{208} \mathrm{~Pb}$. These samples were spiked with $20 \mu \mathrm{g} \mathrm{liter}^{-1}$ of In and $20 \mu \mathrm{g} \mathrm{liter}^{-1}$ of $\mathrm{Tl}$ as internal standard elements.

Unfortunately, Fe could not be measured by ICP-MS because of interferences by the molecular ions ${ }^{40} \mathrm{ArN}^{+},{ }^{40} \mathrm{ArO}^{+}$, and ${ }^{40} \mathrm{ArOH}^{+}$on ${ }^{54} \mathrm{Fe},{ }^{56} \mathrm{Fe}$, and ${ }^{57} \mathrm{Fe}$. As the formation of these molecular ions was not constant in the measuring time, no correct background correction could be made.

Determination of $\mathrm{H}_{2} \mathrm{~S}-\mathrm{H}_{2} \mathrm{~S}$ and $\mathrm{HS}^{-}$were stabilized as $\mathrm{ZnS}$ and treated with $\mathrm{N}, \mathrm{N}^{\prime}$-dimethyl-1,4-phenylenediamine using the reagent kit "Spectroquant 14779 Hydrogensulfid" (Merck AG). The absorbance of the formed methylene blue was measured by MAS at 665 $\mathrm{nm}$ and $298 \mathrm{~K}$. Working standards in the range of $10-500 \mu \mathrm{g} \mathrm{liter}^{-1}$ of sulfide were prepared by dilution of a $\mathrm{Na}_{2} \mathrm{~S}$ solution, which was standardized by iodometric titration.

Further determinations - In situ measurements of temperature, $\mathrm{O}_{2}, \mathrm{pH}$, and conductivity in the lake; $\mathrm{Ca}, \mathrm{Fe}, \mathrm{Mn}, \mathrm{NH}_{4}{ }^{+}, \mathrm{NO}_{3}{ }^{-}$, concentration of particles, and other species in lake water samples and in settling particles were determined as described by Sigg et al. (1991) and Kuhn (1992).

\section{Results and discussion}

Seasonal distribution of Mo concentrations in the water column-Vertical profiles of $\mathrm{Mo}$ (VI) concentrations are presented in Fig. 1. A two-way ANOVA shows that the variances over time and depth are significant at a level of 0.05 . The relative standard deviation (RSD) of 3-4 determinations for each sample was usually better than $2 \%$.

In winter 1989-1990 and 1990-1991, the lake was completely mixed. The average con- centration of $\mathrm{Mo}$ (VI) was $0.47 \mu \mathrm{g} \mathrm{liter}^{-1}$ (RSD $=1.0 \%$ ) on 21 March 1990 and $0.48 \mu \mathrm{g} \mathrm{liter}^{-1}$ (RSD $=0.9 \%)$ on 9 January 1991 . The virtually equal average values and the small relative standard deviations show the homogeneous distribution of Mo(VI) in the lake.

During summer, temperature stratification is established. In the hypolimnion, oxygen is consumed by oxidative degradation of organic matter. The $\mathrm{O}_{2}$ concentration drops below the detection limit of $0.1 \mathrm{mg}$ liter ${ }^{-1}$ at a depth of $10 \mathrm{~m}$ in August. In this period, the concentration of Mo(VI) is higher in the epilimnion, and a small, but significant decrease with depth was found in all profiles from May to September.

In October and November the temperature gradient begins to decrease due to cooling of the surface layers. The profile of the Mo concentration follows the dropping of the thermocline to $10-15 \mathrm{~m}$ (Fig. 1). In the hypolimnion, reducing conditions are indicated by the presence of $\mathrm{Fe}(\mathrm{II})$, of $\mathrm{HS}^{-}$, and of high $\left[\mathrm{NH}_{4}{ }^{+}\right]:\left[\mathrm{NO}_{3}{ }^{-}\right]$in the decpest layers (Fig. 2). HS $^{-}$could be measured at 30 and $31 \mathrm{~m}$ : on 24 October, $14(\mathrm{RSD}=11 \%)$ and $20 \mu \mathrm{mol}$ liter $^{-1}(\mathrm{RSD}=8.4 \%)$; on 24 November, 12 $(\mathrm{RSD}=8.0 \%)$ and $14 \mu \mathrm{mol} \mathrm{liter}{ }^{-1}(\mathrm{RSD}=$ $8.1 \%)$. In all other samples analyzed from higher layers or other days, the concentration of $\mathrm{H}_{2} \mathrm{~S}$ was lower than the practical detection limit of $0.1 \mu \mathrm{mol}$ liter $^{-1}$. The Mo concentration reaches its minimum in the bottom waters. At the sampling on 13 December 1990, the circulation of the whole lake was just starting. The temperature was $279 \mathrm{~K}$ in all depths and an oxygen concentration of $4.9 \mathrm{mg} \mathrm{liter}^{-1}$ could be measured even at a depth of $31 \mathrm{~m}$.

The decrease of the $\mathrm{Mo}(\mathrm{VI})$ concentration in October and November is not caused by reduction or complexation to form a species that is not detected by CA-POL. The profile measured in November 1991 shows no significant difference between Mo concentrations obtaincd by CA-POL or ICP-MS (Table 1). This finding indicates that all Mo is present as dissolved species of $\mathrm{Mo}(\mathrm{VI})$ and not as a stable complex or colloid suspended $\mathrm{MoS}_{2}$ or $\mathrm{MoS}_{3}$ which would only be measured by ICP-MS.

The oxoanion of $\mathrm{W}\left(\mathrm{WO}_{4}{ }^{2-}\right)$ is chemically similar to the molybdate ion and shows the same homogeneous vertical distribution in the Pacific Ocean as Mo (Nakayama et al. 1989). The profile of 12 November 1991 (Table 1) 


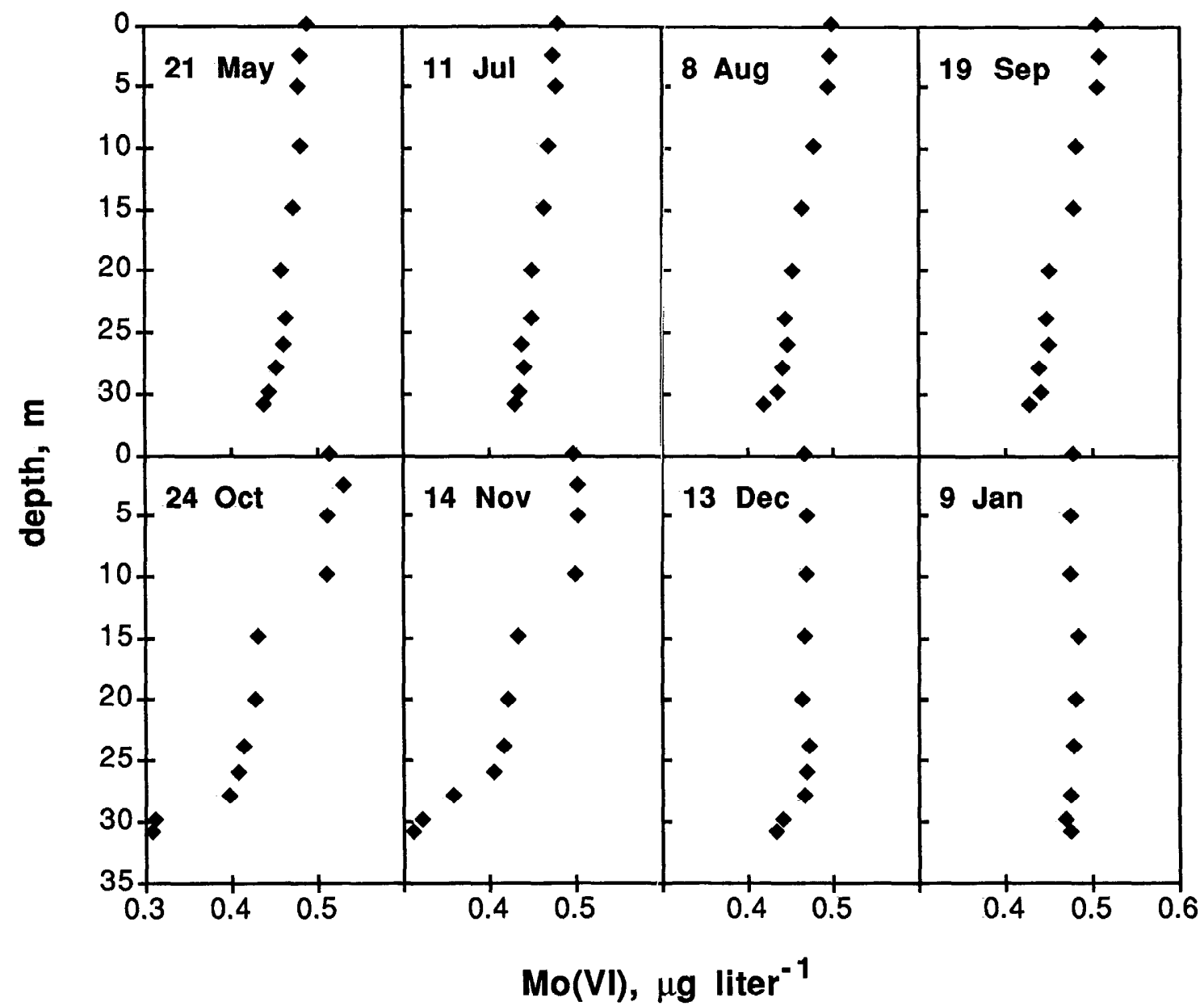

Fig. 1. Vertical profiles of Mo(VI) concentration. Data are average values of $3-4$ determinations by CA-POL; 0.5 $\mu \mathrm{g} \mathrm{liter}^{-1}$ corresponds to $5.21 \mathrm{nmol}^{\text {liter }^{-1}}$.

indicates that the concentration of $\mathrm{W}$ shows a decrease with depth like Mo, though less pronounced. However, there are too few $\mathrm{W}$ results to discuss its behavior in the lake.

On 11 July 1990, 8 August 1990, and 9 January 1991, the concentrations of Mo and Mn were determined by ICP-MS with three different calibration procedures: interpolation with the parameters of a linear regression representing the calibration curve in question; the internal standard procedure; and the method of standard additions. All calibration procedures gave Mo concentrations that were equal to each other within their propagated standard deviations. ICP-MS results (averages and RSDs) are given in Table 1. In the same table the results obtained by independent analytical methods are also compiled. AAS, CA-POL, and ICP-MS are independent methods, because they have different working principles. The agreement of the results obtained by ICPMS and the other methods can be considered good. Data for $\mathrm{Mn}$ were obtained by flame AAS at the Swiss Federal Institute for Water Resources and Water Pollution Control.

Mo in settling particles-Results of the Mo determinations are presented in Table 2. Concentrations of trace clements in settling particles show seasonal variations due to varying composition of the particles with regard to their major components such as organic material, calcium carbonate, manganese oxide, and iron oxide (Sigg et al. 1987). Therefore, fluxes to the sediment traps are more suited to compare 

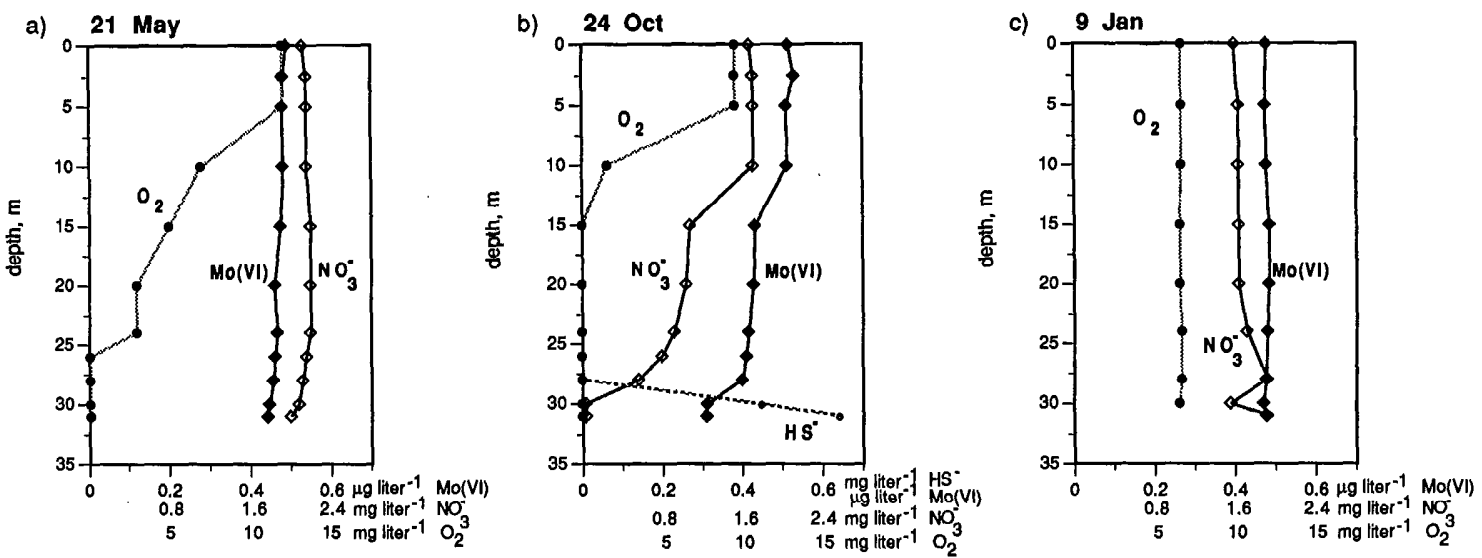

Fig. 2. Depth profiles of $\mathrm{Mo}(\mathrm{VI}), \mathrm{NO}_{3}{ }^{-}, \mathrm{O}_{2}$, and $\mathrm{HS}^{-}$in different seasons. The profiles of $\mathrm{Mo}(\mathrm{VI})$ and $\mathrm{NO}_{3}{ }^{-}$show a significant linear correlation during the stagnation period (July-November).

the behavior of different elements than their concentrations. The fluxes of Mo are in the range from 1.1 to $4.6 \mu \mathrm{g} \mathrm{m}^{-2} \mathrm{~d}^{-1}$ (Fig. 3). No significant trends over time or depth could be detected with two-way ANOVA (at a level of 0.05 ). No significant correlation (at a level of 0.05 ) was found between the fluxes of Mo and $\mathrm{Fe}, \mathrm{Mn}, \mathrm{Ca}$, and organic $\mathrm{C}$ by a multivariate regression analysis.

The transport of a metal in an aquatic system depends strongly on the distribution between particles and water. Distribution coefficients and residence times in the lake can be calculated after Schindler (1984):

$$
K_{d}=c_{s} \times c_{w}{ }^{-1}
$$

where $K_{d}$ is the distribution coefficient (liters $\left.\mathrm{g}^{-1}\right), c_{s}$ the concentration in the solid phase ( $\mu \mathrm{g}$ $\mathrm{g}^{-1}$ ), and $c_{w}$ the concentration in the soluble phase $\left(\mu \mathrm{g} \mathrm{liter}^{-1}\right)$. Distribution coefficients of $\mathrm{Fe}, \mathrm{Mn}, \mathrm{Ca}$, and Mo are given in Table 3. The distribution coefficients in July are generally lower than in January (with the exception of Ca) due to the high fraction of $\mathrm{CaCO}_{3}$ in summer. The marked difference of $\mathrm{Mn}$ results from reduction of particulate $\mathrm{Mn}$ oxides to soluble $\mathrm{Mn}(\mathrm{II})$ under reducing conditions in summer. Mo has relatively low $K_{d}$ values. By comparing the fraction $f$ of dissolved Mo $\left(c_{w}\right)$ to total Mo $\left(c_{t}\right)$, we can calculate the speciation of Mo with the concentration of suspended matter $S$ and $K_{d}$ :

$$
f=c_{w} c_{t}^{-1}=\left(1+K_{d} S\right)^{-1} .
$$

Table 1. Comparison of results obtained by different analytical methods used to control the reliability of the results (total concentrations in unfiltered, acidified samples). Results by ICP-MS are average values of six-nine determinations;

\begin{tabular}{|c|c|c|c|c|c|c|c|}
\hline & Element & $\begin{array}{l}\text { Depth } \\
\text { (m) }\end{array}$ & $\begin{array}{c}\text { ICP-MS } \\
\left(\mu \text { g liter }{ }^{\prime}\right)\end{array}$ & $\begin{array}{l}\text { RSD } \\
(\%)\end{array}$ & $\begin{array}{c}\text { CA-POL } \\
\left(\mu \text { liter }^{-1}\right)\end{array}$ & $\begin{array}{l}\text { RSD } \\
(\%)\end{array}$ & $\begin{array}{c}\text { AAS* }^{*} \\
\left(\mu \mathrm{g} \mathrm{liter}^{-1}\right)\end{array}$ \\
\hline \multirow[t]{2}{*}{11 Jun 90} & Mo & 5 & 0.49 & 4.0 & 0.48 & 0.7 & - \\
\hline & $\mathrm{Mn}$ & 5 & 3.0 & 2.3 & - & - & 3.0 \\
\hline \multirow[t]{2}{*}{8 Aug 90} & Mo & 5 & 0.44 & 5.3 & 0.50 & 0.9 & - \\
\hline & Mn & 5 & 0.58 & 2.6 & - & - & 0.8 \\
\hline \multirow[t]{3}{*}{9 Jan 91} & Mo & 5 & 0.47 & 5.9 & 0.48 & 1.9 & - \\
\hline & $\mathrm{Mn}$ & 5 & 12 & 3.3 & - & - & 12 \\
\hline & W & 5 & 0.02 & 27 & - & - & - \\
\hline \multirow[t]{6}{*}{12 Nov 91} & Mo & 10 & 0.57 & 6.1 & 0.52 & 0.2 & - \\
\hline & Mo & 30 & 0.36 & 9.7 & 0.38 & 0.5 & - \\
\hline & Mo & 31 & 0.36 & 7.2 & 0.35 & 4.0 & - \\
\hline & W & 10 & 0.023 & 3.9 & - & - & - \\
\hline & W & 30 & 0.020 & 4.4 & - & - & - \\
\hline & W & 31 & 0.019 & 7.9 & - & - & - \\
\hline
\end{tabular}
results by CA-POL three determinations.

* Atomic absorption spectrometry. 
Table 2. Concentration of Mo ( $\left.\mu \mathrm{gg}{ }^{\prime}\right)$ in settling particles. Results are average of three ICP-MS determinations.

\begin{tabular}{lccccc}
\hline \hline \multirow{2}{*}{$\begin{array}{c}\text { Sampling } \\
\text { period }\end{array}$} & \multicolumn{2}{c}{$15 \mathrm{~m}$} & & \multicolumn{2}{c}{$28 \mathrm{~m}$} \\
\cline { 6 - 7 } \cline { 6 - 7 } & Mo & SD & & Mo & SD \\
\hline 17 Oct-21 Nov 89 & 0.79 & 0.01 & & 2.80 & 0.13 \\
21 Nov-12 Dec 89 & 1.12 & 0.04 & & 1.21 & 0.07 \\
12 Dec-15 Jan 90 & 1.44 & 0.08 & & 1.26 & 0.08 \\
15 Jan-26 Feb 90 & 1.33 & 0.06 & & 1.35 & 0.03 \\
26 Apr-21 May 90 & 1.61 & 0.03 & & 1.61 & 0.07 \\
21 May-12 Jun 90 & 0.22 & 0.01 & & 0.30 & 0.03 \\
12 Jun-12 Jul 90 & 0.31 & 0.01 & & 0.65 & 0.03 \\
12 Jul-2 Aug 90 & 0.46 & 0.04 & & 0.44 & 0.04 \\
2-30 Aug 90 & 0.46 & 0.04 & & 0.40 & 0.05 \\
30 Aug-27 Sep 90 & 0.62 & 0.08 & & 0.61 & 0.06 \\
27 Sep-22 Oct 90 & 0.86 & 0.06 & & 1.13 & 0.07 \\
22 Oct-8 Nov 90 & 1.29 & 0.07 & & 1.23 & 0.04 \\
8-27 Nov 90 & 1.77 & 0.07 & & 2.01 & 0.05 \\
27 Nov-18 Dec 90 & 1.70 & 0.03 & & 1.81 & 0.04 \\
18 Dec-9 Jan 91 & 1.90 & 0.03 & 2.79 & 0.04 \\
\hline
\end{tabular}

About $99 \%$ of total Mo is present as dissolved Mo(VI).

If we assume a steady state, the residence time $t_{A}(\mathrm{~d})$ of a metal that is removed from the lake by particle sedimentation (precipitation or adsorption on settling particles) and by the outflow is

$$
t_{A}^{-1}=t_{w}^{-1}+t_{s}^{-1}=t_{w}^{-1}+\left[F_{A}\left(h c_{t}\right)^{-1}\right]
$$

$t_{w}$ is the residence time of water in the lake (d), $t_{s}$ the residence time of the metal due to particle settling (d), $F_{A}$ the average flux of the element during exposition time (usually 3 wceks), measured in the trap at $28 \mathrm{~m}\left(\mathrm{mg} \mathrm{m}^{-2} \mathrm{~d}^{-1}\right), h$ the depth of the lake $(\mathrm{m})$, and $c_{t}$ the average total concentration of the metal in the lake $\left(\mathrm{mg} \mathrm{m}^{-3}\right)$. Results are listed in Table 3. Residence times depend on the $K_{d}$ of a substance and are between the residence time of water, which is determined by the water renewal time, and the residence time of particles, which corresponds to a substance only present in particulate form. The shortest residence time is $t_{\mathrm{Fe}}$, because most of the time $\mathrm{Fe}$ is present as particulate $\mathrm{FeOOH}$. It is not possible to calculate the residence time of $\mathrm{Mn}$ in this way because of the cycling in the deepest layers. The difference of $t_{\mathrm{Ca}}$ in July and in January is caused by high sedimentation rates of $\mathrm{CaCO}_{3}$ in summer. The long residence times and low distribution coefficients of $\mathrm{Ca}$

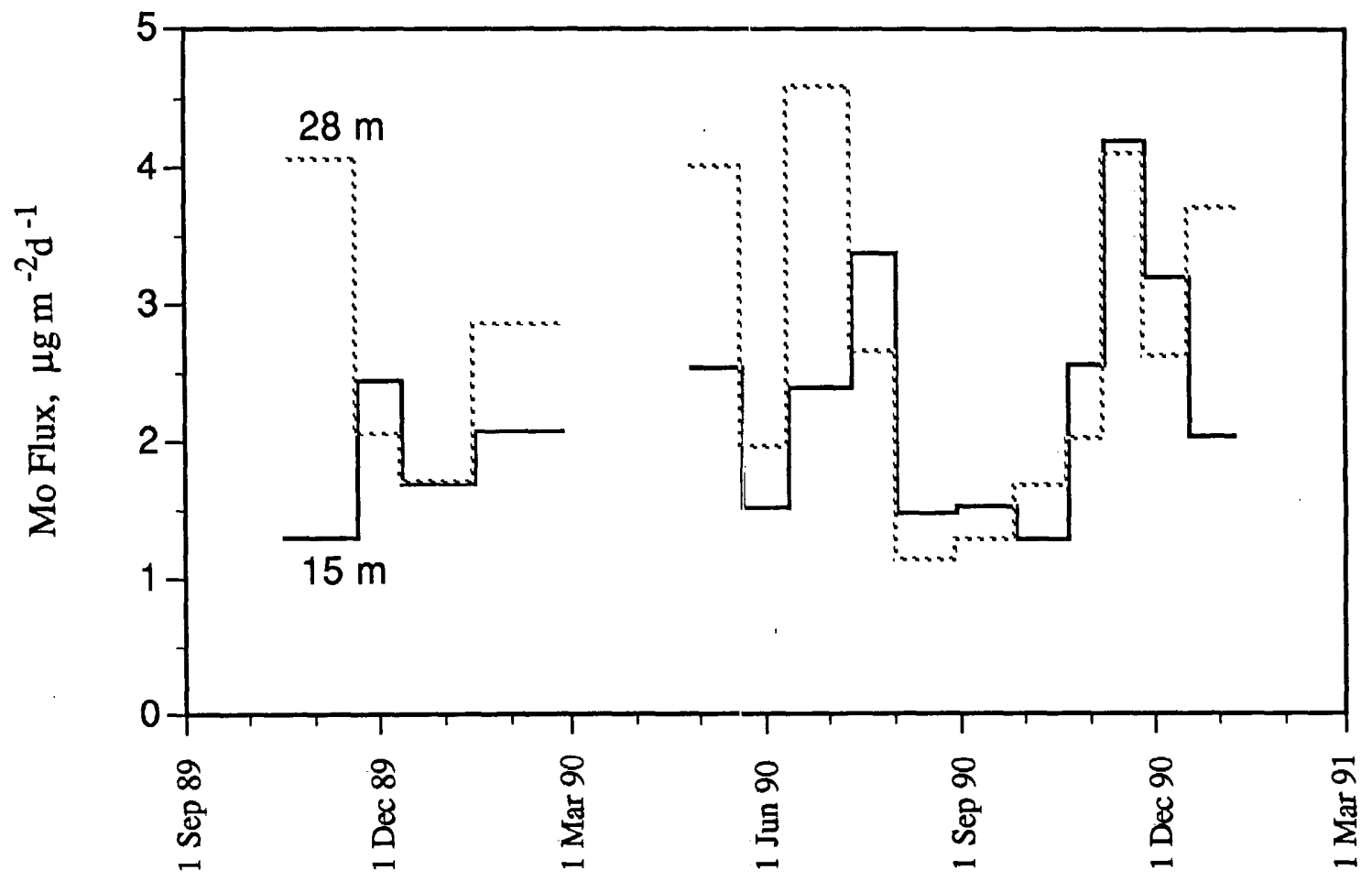

Fig. 3. Vertical fluxes of particle-bound Mo, calculated with average values of three determinations by ICP-MS. 
and Mo show the high mobility of these elements and the low affinity of Mo for solid phases. During the whole year, $t_{\mathrm{Mo}}$ is close to $t_{w}$, because the total inventory of Mo in the lake is high relative to the amount removed by precipitation or adsorption and subsequent sedimentation. This behavior corresponds to that of Mo, which is expected for chemical reasons and from its distribution in oceans.

The adsorption of $\mathrm{MoO}_{4}{ }^{2-}$ on $\mathrm{Mn}$ oxides depends strongly on the $\mathrm{pH}$ of the solution. The $\mathrm{pH}$ values in the lake are regulated, in addition to $\mathrm{CaCO}_{3}$ equilibria, by biological production and oxidative degradation of organic matter and were found to vary in the range of 7.3-7.9. The seasonal change of $\mathrm{pH}$ causes a change of the distribution between adsorbed and dissolved Mo(VI) and makes correlation between Mo and Mn fluxes impossible. Assuming that the particulate fraction of Mo is adsorbed on Mn oxides, a distribution coefficient $K_{d, \mathrm{Mn}}$ can be used to calculate the distribution between Mo bound to $\mathrm{Mn}$ and the soluble Mo fraction. The concentration $c_{s}$ (mass of Mo per mass of particle) is replaced by $c_{s(\mathrm{Mo})} c_{s(\mathrm{Mn})}{ }^{-1}$ (mass Mo per mass of particulate $\mathrm{Mn}$ ):

$$
K_{d, \mathrm{Mn}}=c_{s(\mathrm{Mo})}\left[c_{s(\mathrm{Mn})} c_{w(\mathrm{Mo})}\right]^{-1}
$$

with $K_{d, \mathrm{Mn}}$ in liters $\mathrm{g}^{-1} \mathrm{Mn}_{p}$. A linear approach for this narrow $\mathrm{pH}$ range is statistically significant (at a level of 0.01): $K_{d, \mathrm{Mn}}=57,000-7,200$ $\times \mathrm{pH}$. It indicates the possible role of particulatc Mn oxides as carriers for Mo in this lake. The particle flux of Mn in January is $~ 10$ times higher than in July, while the Mo flux remains constant (Table 3). This can be explained by the corresponding $K_{d, \mathrm{Mn}}$ values of 1,700 liters $\mathrm{g}^{-1}$ in July and 160 in January.

\section{Models of transport mechanisms for Mo in lake water}

Mn oxides and hydroxides are stable in water only under oxic conditions. In Lake Greifen, particulate $\mathrm{Mn}\left(\mathrm{Mn}_{p}\right)$ was found in winter in all depths, but in summer only in the epilimnion. Mn oxides and hydroxides are excellent carriers for molybdate under oxic conditions and could be responsible for the particle-bound flux of Mo between December and March and in summer only in the epilimnion.

Bertine (1972) proposed coprecipitation of $\mathrm{MoS}_{3}$ on FeS according to
Table 3. Calculated distribution coeflicients and residence times. $K_{d}$ (liters $\mathrm{g}^{-1}$ ) was calculated from the concentration in the solid phase (measured in the $28-\mathrm{m}$ trap) and the concentration in the soluble phase (average concentration in the water column). The residence time (d) of particles was calculated from total particle flux and concentration of suspended particles in lake-water samples. Data for $\mathrm{Fe}, \mathrm{Mn}, \mathrm{Zn}, \mathrm{Ca}$, and particles were obtained from the Swiss Federal Institute for Water Resources and Water Pollution Control.

\begin{tabular}{|c|c|c|c|c|}
\hline Species & Month & $K_{d}$ & (mg m ' $F^{\prime}$ d ') & $t .1$ \\
\hline \multirow[t]{2}{*}{ Particles } & Jul & - & 7,100 & 3.5 \\
\hline & Jan & - & 1,300 & 30 \\
\hline \multirow[t]{2}{*}{$\mathrm{Fe}$} & Jul & 190 & 18 & 22 \\
\hline & Jan & 1,000 & 12 & 22 \\
\hline \multirow[t]{2}{*}{$\mathrm{Mn}$} & Jul & 8.1 & 6.2 & - \\
\hline & Jan & 2,000 & 51 & - \\
\hline \multirow[t]{2}{*}{$\mathrm{Zn}$} & Jul & 34 & 0.49 & 99 \\
\hline & Jan & 240 & 0.52 & 79 \\
\hline \multirow[t]{2}{*}{$\mathrm{Ca}$} & Jul & 5.5 & 2,200 & 270 \\
\hline & Jan & 2.6 & 220 & 390 \\
\hline \multirow[t]{2}{*}{ Mo } & Jul & 1.4 & 0.0046 & 360 \\
\hline & Jan & 5.8 & 0.0037 & 370 \\
\hline \multirow[t]{2}{*}{ Water } & Jul & - & - & 408 \\
\hline & Jan & - & - & 408 \\
\hline
\end{tabular}

$$
\begin{aligned}
\mathrm{FeS}_{\text {amorphous }} & +\mathrm{MoO}_{2} \mathrm{~S}_{2}{ }^{2-}+\mathrm{H}_{2} \mathrm{~S}+2 \mathrm{H}^{+} \\
& =\mathrm{FeS} \cdot \mathrm{MoS}_{3, \text { amorphous }}+2 \mathrm{H}_{2} \mathrm{O} .
\end{aligned}
$$

In marine systems, this transport mechanism is well known (Van der Weijden et al. 1990; Emerson and Huested 1991). In the samples, in which $\mathrm{H}_{2} \mathrm{~S}$ could be measured, a marked reduction of the $\mathrm{Mo}(\mathrm{VI})$ concentration was detected. The results from the sediment trap material give no hint for precipitation of $\mathrm{MoS}_{2}$ or coprecipitation of $\mathrm{MoS}_{3}$ on $\mathrm{FeS}$, but the trap at $28 \mathrm{~m}$ was probably too high to collcct these species. The profiles from May to September, when $\mathrm{H}_{2} \mathrm{~S}$ is not yet formed, indicate that at least a second transport mechanism is involved.

Trace elements such as Mo are incorporated into phytoplankton during photosynthesis in the surface layer. After settling and oxidative mineralization of the biomass, they are released. A typical nutrient profile in a lake shows depletion in the epilimnion and enrichment in the hypolimnion (Sigg 1985). The observed Mo profiles did not correspond to this behavior. Although this process will transport a certain amount of Mo, we concluded that the contribution of this process is too small to influence the distribution of Mo significantly.

The form of the profiles in autumn is char- 
acteristic for a substance that is consumed by processes at the sediment-water interface or in the pore water of fresh sediment. Nitrate is bacterially reduced to $\mathrm{N}_{2}$ at the sediment-water interface (Höhener 1990). The profiles of Mo and $\mathrm{NO}_{3}{ }^{-}$for 24 October (Fig. 2) and 14 November are linearly correlated with correlation coefficients of 0.99 . The similarity of the profiles leads to the conclusion that $\mathrm{Mo}$ (VI) could also be consumed at this boundary layer. The following consumption processes for Mo are proposed. First, coprecipitation of $\mathrm{MoS}_{3}$ on $\mathrm{FeS}$ in the pore water, even if no $\mathrm{HS}^{-}$is detectable. The conditions in the fresh sediment are more reducing than in the water column. Second, uptake by nitrate-reducing bacteria for synthesis of nitrate reductase, a Mo-containing enzyme. Mo can be a factor limiting primary production in lakes when $\mathrm{NO}_{3}{ }^{-}$is the nitrogen source and Mo concentrations are $\leq 0.06 \mu \mathrm{g} \mathrm{liter}^{-1}$ (Goldman 1960, 1964). Third, reduction to $\mathrm{Mo}(\mathrm{V})$ and complexation by organic material. This process is known in organic C-rich marine sediments (Brumsack and Gieskes 1983). The consumption process causes a sink for Mo at the sediment-water interface, and Mo is transported to this boundary layer by turbulent diffusion.

\section{Model calculations with CHEMSEE}

For each of the three possible transport mechanisms, a lake model was established with CHEMSEE. The one-dimensional vertical model used in the program was published by Imboden and Schwarzenbach (1985). Vertical transport is described by a time- and depthdependent eddy diffusion coefficient, which is calculated by the temperature method (Imboden et al. 1979) with measured temperature profiles. Horizontal concentration gradicnts are neglected by this one-dimensional vertical model. Horizontal mixing is assumed to be fast compared to reactions and fluxes at the lateral boundaries (Imboden and Schwarzenbach 1985).

Field data of 1 April (interpolation of measured Mo profiles of 21 March and 21 May) were input values for the calculations. To replace the Mo which is transported to the sediment by one of the mechanisms, we had to include the unknown concentration of the inflows $c_{\text {in }}$ in optimization because it was not possible to mcasure inflow concentrations. The Mo concentration of the outflow is equal to the concentration in the top layer of the lake. The simulated profiles were fitted to the field data by systematic variation of the unknown parameters.

Adsorption on $M n_{\mathrm{p}}$-Measured values for $\mathrm{Mn}_{p}$ were used. To describe the $\mathrm{pH}$-dependent distribution between soluble Mo and Mo adsorbed on $\mathrm{Mn}_{p}$, we used three different values of $K_{d, \mathrm{Mn}}$ according to the seasonal variation (838 liters $\mathrm{g}^{-1}<K_{d, \mathrm{Mn}}<3,160$ liters $\mathrm{g}^{-1}$ ). The median velocity of sedimentation was calculated from the sediment trap data $\left(v_{\mathrm{sed}}=F_{A}\right.$ $\left.c_{t}^{-1}=1.125 \mathrm{~m} \mathrm{~d}^{-1}\right)$. The inflow concentration $c_{\text {in }}$ was fitted to $0.60 \mu \mathrm{g}$ liter $^{-1}$. Simulated and field data profiles are presented in Fig. 4a. The simulated profiles show the decrease in June and September, but the sharp decrease in the deepest few meters in November cannot be simulated. In January all models will find a homogeneous distribution after the complete mixing of the lake.

Precipitation in the presence of $\mathrm{HS}^{-}-\mathrm{The}$ exact stoichiometry of the possible coprecipitation or precipitation reaction is not known. It is reasonable to use a second-order rate law: $\mathrm{d} c(\mathrm{Mo}) \mathrm{d} t^{-1}=k c(\mathrm{Mo}) c\left(\mathrm{HS}^{-}\right)$for the model. For $\mathrm{HS}^{-}$, measured concentrations were used. The rate constant was fitted to $k=-5$ liters $(\mathrm{mmol} \mathrm{d})^{-1}, c_{\text {in }}$ to $0.52 \mu \mathrm{g} \mathrm{liter}^{-1}$. Profiles are presented in Fig. 4b. In June and September, the calculations show an increase of the epilimnion concentration due to inflow. Elimination does not yet occur, because $\mathrm{HS}^{-}$was detected only in October and November. On 1 November, a very marked decrease is found, corresponding to the measured data. It is not possible to simulate the step between 10 and $15 \mathrm{~m}$ with this mechanism.

Consumption process at the sediment-water interface-The consumption process is described as a zeroth-order flux to the sediment $F$ :

$$
\partial c_{l} \partial t^{-1}=(F \mathrm{~d} A)(A \mathrm{~d} z)^{-1}
$$

with the flux $F\left(\mu \mathrm{g} \mathrm{m}^{-2} \mathrm{~d}^{-1}\right)$ and the lake area $A\left(\mathrm{~m}^{2}\right)$ in depth $z(\mathrm{~m})$. The factor $\mathrm{d} A(A \mathrm{~d} z)^{-1}$ describes the local ratio of sediment area to volume $\mathrm{d} A: \mathrm{d} V$. All proposed reactions can occur only in the absence of dissolved $\mathrm{O}_{2}$, so $\mathrm{O}_{2}$ was introduced as the trigger variable: the 


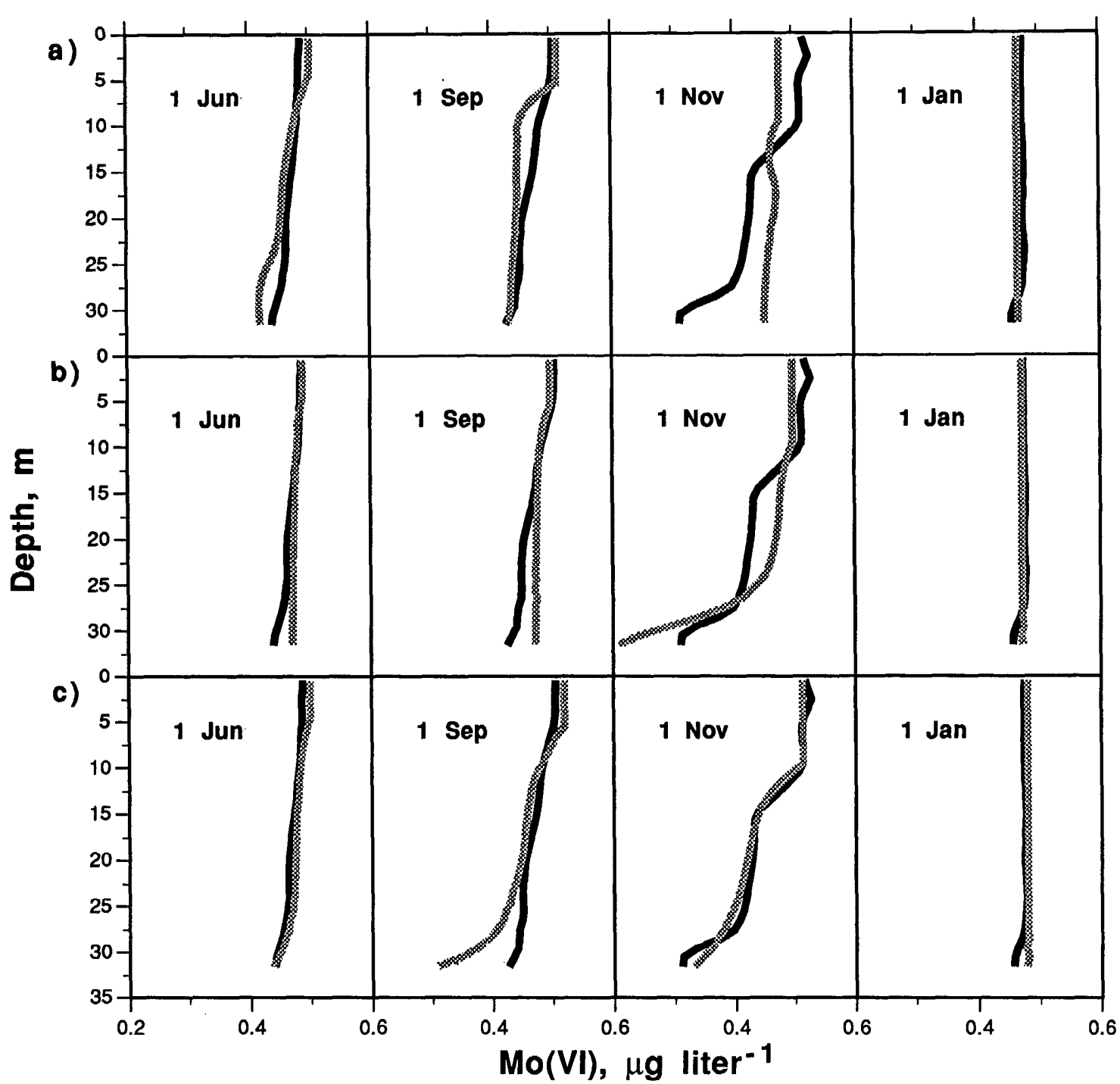

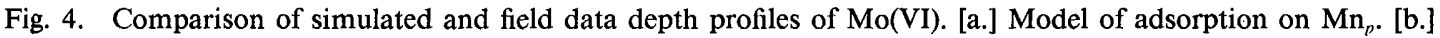
Model of precipitation in the presence of $\mathrm{HS}^{-}$. [c.] Model of the consumption process at the sediment. Black linesfield data (interpolation of measured values); gray lines-model calculations with CHEMSEE.

process will be active only if the concentration of $\mathrm{O}_{2}$ is $<1 \mathrm{mg}$ liter ${ }^{-1}$. It was necessary because no measured data exist for this model, except Mo(VI) concentrations. The constant sediment flux was fitted to $F=-5 \mu \mathrm{g} \mathrm{m}^{-2} \mathrm{~d}^{-1}, c_{\text {in }}$ to $0.56 \mu \mathrm{g} \mathrm{liter}^{-1}$. These profiles are given in Fig. 4c. The coincidence with the field data is quite good. The flux $F$ seems to be overestimated in September and would obviously be time-dependent according to changing redox conditions. The correct modeling of the step between 10 and $15 \mathrm{~m}$ in November indicates the role of the sediment area, because there is a change in the lake cross section at this depth.

All three transport mechanisms can occur in the lake. There are too many unknown parameters to quantify the influence of each process. The first model yields an inflow concentration that is not expected for the residence time of Mo. Residence times were calculated for only two dates using a one-box-model, whereas results from CHEMSEE calculations 
are based on all measured data and on a lake model of 32 horizontal boxes. The CHEMSEE simulation for this model was difficult, because the distribution coefficient $K_{d, \mathrm{Mn}}$ is not constant during the year. Such behavior is not provided by the original model and may bc the reason for the relatively high calculated inflow concentration. The model calculations show that the measured profiles can be principally explained and simulated with the proposed mechanisms.

\section{Conclusions}

Catalytic adsorption polarography (CAPOL) is very suitable to study the distribution of Mo(VI) in natural waters, because it allows direct determination of the Mo(VI) concentration. If correlation with other metals is also attempted, a second method with comparable sensitivity and precision is needed. For this purpose the inductively coupled plasma mass spectrometry (ICP-MS) is the best possibility.

The concentration of Mo in the lake is relatively homogeneous and conservative. The residence time of Mo is close to the water residence time. A decrease with depth during the stagnation period is caused by different elimination processes. The most probable transport mechanisms for Mo in this eutrophic lake with a seasonally anoxic hypolimnion seem to be transport of $\mathrm{Mo}(\mathrm{VI})$ as $\left\{\mathrm{FeS} \cdot \mathrm{MoS}_{3}\right\}$ in the presence of $\mathrm{H}_{2} \mathrm{~S}$; a low, rather constant flux of Mo bound to settling particles, probably $\mathrm{Mn}$ oxides and hydroxides; and turbulent diffusion of $\mathrm{Mo}(\mathrm{VI})$ to a sink in the pore water or at the sediment-water interface, caused by chemical or biological processes. The observed profiles are the result of a combination of these mechanisms.

\section{References}

Berrang, P. G., AND E. V. Grill. 1974. The effect of manganese oxide scavenging on molybdenum in Saanich Inlet, British Columbia. Mar. Chem. 2: 125148.

Bertine, K. K. 1972. The deposition of molybdenum in anoxic waters. Mar. Chem. 1: 43-53.

BRUMSACK, H. J., AND J. M. Gieskes. 1983. Interstitial water trace-metal chemistry on laminated sediments from the Gulf of California, Mexico. Mar. Chem. 14: 89-106.

Collier, R. W. 1985. Molybdenum in the northeast Pacific Ocean. Limnol. Oceanogr. 30: 1351-1354.
Emerson, S. R., ANd S. S. Huested. 1991. Ocean anoxia and the concentrations of molybdenum and vanadium in seawater. Mar. Chem. 34: 177-196.

Goldman, C. R. 1960. Molybdenum as a factor limiting primary productivity in Castle Lake, California. Science 132: 1016-1017.

- 1964. Primary productivity and micro-nutrient limiting factors in some North American and New Zealand lakes. Int. Ver. Theor. Angew. Limnol. Verh. 15: 365-374.

HöHENER, P. 1990. Der Stickstoffhaushalt von Seen, illustricrt am Beispiel des Sempachersees. Ph.D. thesis 9157, Swiss Fed. Inst. Technol., Zürich. 132 p.

Imboden, D. M., B. S. F. Eid, T. Joller, M. SChURTER, AND J. WETZEL. 1979. MELIMEX, an experimental heavy metal pollution study: Vertical mixing in a large limno-corral. Schweiz. Z. Hydrol. 41: 177-189.

- - AND R. P. SCHWARZENBACH. 1985. Spatial and temporal distribution of chemical substances in lakes: Modeling concepts, p. 1-30. In W. Stumm [ed.], Chemical processes in lakes. Wiley-Interscience.

Johinson, C. A., M. UlRICH, L. SigG, AND D. M. IMBODEN. 1991. A mathematical model of the manganese cycle in a seasonally anoxic lake. Limnol. Oceanogr. 36: 1415-1426.

KoIDE, M., AND OTHERS. 1986. Some comparative marine chemistries of rhenium, gold, silver, and molybdenum. Appl. Geochem. 1: 705-714.

Kurin, A. 1992. Arsen im eutrophen See: Einc Studie der saisonalen Redoxprozesse. Ph.D. thesis 9783, Swiss Fed. Inst. Technol., Zürich. 96 p.

Magyar, B., ann S. Wunderli. 1986. Polarographic determination on nanomolar concentrations of molybdenum(VI). Mikrochim. Acta (Wien) 1985(3): 223237.

Manheim, F., And S. LANdergren. 1978. Molybdenum; abundance in sediments and sedimentary rocks, p. 42-K-1 to 42-K-14. In Handbook of geochemistry. V. 2, part 4. Springer.

Najsayama, E., Y. Suzuki, K. Fujiwara, and Y. Kitano. 1989. Chemical analyses of seawater for trace elements. Recent progress in Japan for clean sampling and chemical speciation of trace clements. Anal. Sci. 5: 129-139.

SCH:INDLER, P. W. 1984. Surface complexation, p. 105135. In H. Sigel [ed.], Metal ions in biological systems. V. 18. Dekker.

SigG, L. 1985. Metal transfer mechanisms in lakes; the role of settling particles, p. 283-310. In W. Stumm [ed.], Chemical processes in lakes. Wiley-Interscience.

- - C. A. Johnson, AND A. Kunn. 1991. Redox conditions and alkalinity generation in a seasonally anoxic lake (Lake Greifen). Mar. Chem. 36: 9-26.

- - M. STURM, AND D. Kistler. 1987. Vertical transport of heavy metals by settling particles in Lake Zurich. Limnol. Occanogr. 32: 112-130.

SOINNENSCHEIN, W., AND K. SchÄFER. 1953. Über eine Methode zur gleichzeitigen Bestimmung kleinster Mengen von Schwefelwasserstoff und Schwefelkohlenstoff in der Luft. Fresenius Z. Anal. Chem. 140: 15-25.

Stabel, H. H., J. Kleiner, P. Merkel, AND H. W. Sinemus. 1991. Cycling of some trace elements in Lake Constance. Vom Wasser 76: 73-91. 
Sugawara, K., S. Okabe, and M. Tanaka. 1961. Gcochemistry of molybdenum in natural waters (II). J. Earth Sci. Nagoya Univ. 9: 114-128.

Ulrich, M. 1991. Modeling of chemicals in lakes-development and applications of user-friendly simulation software (MASAS \& CHEMSEE) on personal computers. Ph.D. thesis 9632, Swiss Fed. Inst. Technol., Zürich. 213 p.

VAN DER Weijden, C. H., AND others. 1990. Profiles of the redox-sensitive trace elements $\mathrm{As}, \mathrm{Sb}, \mathrm{V}, \mathrm{Mo}$, and $\mathrm{U}$ in the Tyro and Bannock Basins (eastern Mediterranean). Mar. Chem. 31: 171-186.

Submitted: 5 August 1992 Accepted: 4 January 1993 Revised: 3 February 1993 